\title{
Formulation of Microbial Inoculants by Encapsulation in Natural Polysaccharides: Focus on Beneficial Properties of Carrier Additives and Derivatives
}

\begin{abstract}
Nikolay Vassilevi*, Maria Vassileva'1, Vanessa Martos², Luis F. Garcia del Moral², Jolanta Kowalska ${ }^{3}$, Bartosz Tylkowski ${ }^{4}$ and Eligio Malusá ${ }^{5}$

'Department of Chemical Engineering, Institute of Biotechnology, University of Granada, Granada, Spain, ${ }^{2}$ Department of Plant Physiology, University of Granada, Granada, Spain, ${ }^{3}$ Institute of Plant Protection - National Research Institute, Poznań, Poland, ${ }^{4}$ Chemical Technology Unit, Technology Centre of Catalonia, Tarragona, Spain, ${ }^{5}$ Research Institute of Horticulture, Skierniewice, Poland
\end{abstract}

OPEN ACCESS

Edited by:

Brigitte Mauch-Mani,

Université de Neuchâtel, Switzerland

Reviewed by:

Lata Nain,

Indian Agricultural Research Institute

(ICAR), India

Jitendra Mishra,

Babasaheb Bhimrao Ambedkar

University, India

*Correspondence:

Nikolay Vassilev

nbvass@yahoo.com

Specialty section: This article was submitted to

Plant Microbe Interactions,

a section of the journal

Frontiers in Plant Science

Received: 27 December 2019

Accepted: 20 February 2020

Published: 10 March 2020

Citation:

Vassilev N, Vassileva M, Martos V,

Garcia del Moral LF, Kowalska J,

Tylkowski B and Malusá E (2020)

Formulation of Microbial Inoculants by

Encapsulation in Natural

Polysaccharides: Focus on Beneficial

Properties of Carrier Additives

and Derivatives.

Front. Plant Sci. 11:270.

doi: 10.3389/fp/s.2020.00270
In the last 10-15 years, the wide application of bioformulated plant beneficial microorganisms is accepted as an effective alternative of chemical agro-products. Two main problems can be distinguished in their production and application: (a) economical competiveness based on the overall up-stream and down-stream operational costs, and (b) development of commercial products with a high soil-plant colonization potential in controlled conditions but not able to effectively mobilize soil nutrients and/or combat plant pathogens in the field. To solve the above problems, microbe-based formulations produced by immobilization methods are gaining attention as they demonstrate a large number of advantages compared to other solid and liquid formulations. This mini-review summarizes the knowledge of additional compounds that form part of the bioformulations. The additives can exert economical, price-decreasing effects as bulking agents or direct effects improving microbial survival during storage and after introduction into soil with simultaneous beneficial effects on soil and plants. In some studies, combinations of additives are used with a complex impact, which improves the overall characteristics of the final products. Special attention is paid to polysaccharide carriers and their derivates, which play stimulatory role on plants but are less studied. The mini-review also focuses on the potential difficulty in evaluating the effects of complex bio-formulations.

Keywords: biofertilizers, formulation, immobilization, polysaccharides, additives

\section{INTRODUCTION}

Different groups of soil microorganisms, such as root endophytic fungi, mycorrhizal fungi, plant growth-promoting rhizobacteria, rhizobia, and phosphate solubilizers affect plant growth through direct and plant-mediated mechanisms, including in stressed conditions (van der Heijden et al., 2008; Berg, 2009; Shilev et al., 2019). The application of selected plant beneficial microorganisms individually or as microbial consortia with multifunctional properties is an important tool to 
promote crop health and productivity (Ahmad et al., 2018; Maron et al., 2018). The scientific literature abounds in studies on isolation and characterization of plant-beneficial microorganisms, but only few of them have reached the commercial market. Many commercial bio-inoculants do not work under field conditions with the efficiency demonstrated in greenhouse or laboratory experiments (Stephens and Rask, 2000; Vassilev et al., 2015; Arora and Mishra, 2016; Malusá et al., 2016) due to inadequate and/or poor quality formulation, including poor compatibility and stability of the carriers (Bhattacharyya and Jha, 2012; Bashan et al., 2016; Baez-Rogelio et al., 2017; Stamenkovic et al., 2018).

The main roles of the formulation of inoculants are: (i) to provide a more suitable micro-environment for the microbial strain/s, combined with physical or chemical protection over a prolonged period, in order to avoid a rapid decrease of the cells' viability during storage, (ii) to support the strain/s competition with the better-adapted native soil microflora, and (iii) to reduce losses due to the depredation by the micro-fauna after being introduced into soil. All these functions are aiming at providing a reliable source of living cells available to interact with plants and soil microbiome (Bashan, 1998; Herrmann and Lesueur, 2013; Bashan et al., 2014; Malusá and Vassilev, 2014). Indeed, a critical number of cells are essential to obtain the expected positive response from the formulated inoculum $\left(10^{6}-10^{7}\right.$ cells/plant; Bashan, 1986).

Different microbial formulations have been developed using liquid or solid materials as carriers. Liquid inoculants are microbial cultures modified with water, oil or polymers (i.e., additives) that improve cell-suspension viscosity, stability and dispersion capacity (Catroux et al., 2001; Bashan et al., 2016; Malusá et al., 2016). The problem with this type of products is that the microbial population and its metabolic activity decrease rapidly after the introduction of cell suspensions into the soil, particularly if they are not containing suitable additives. A special attention has been paid in the recent years on cell-free formulations (Bashan et al., 2016) like fermentation broth filtrates (Kumar et al., 2012; Vinale et al., 2014; Vassilev et al., 2017). Since some plant beneficial microorganisms demonstrated multiple activities (Vassileva et al., 2010), their culture extracts contain various metabolic products such as antibiotics, siderophores, toxins, lytic enzymes (Thrane et al., 1997; Aydi-Ben Abdallah et al., 2014), and solubilized phosphate (Mendes et al., 2017; Vassilev et al., 2017), which positively affect the plant growth. Such type of products and the related strategy can be denominated as post-biotic.

The solid formulations are based on inorganic or organic carriers, prepared in solid, granular, or powdery forms and classified according to their particle sizes or application mode (Adholeya and Das, 2012; Malusá et al., 2012; Stamenkovic et al., 2018). The most important solid formulations are based on carriers such as peat, compost, agro-industrial wastes, vermiculite, perlite, rock phosphate, calcium sulfate, and polysaccharides (Sahu and Brahmaprakash, 2016). In the recent years, in the field of solid formulation technologies, more attention is paid to polysaccharide-immobilized inoculants (Malusá et al., 2016) as well as to inoculants produced under solid-state fermentation (SSF) conditions using agro-industrial wastes (Vassilev and Mendes, 2018). SSF processes offer many advantages including co-cultivation of two microorganisms, enrichment with soluble P (Mendes et al., 2015), induction of biocontrol activity (Vassilev et al., 2009), as well as the use of solid substrates alone, combined, and moistened with liquid wastes (Vassilev and Mendes, 2018). However, the gelcell immobilized approach is the technological solution that can better assure a standardization of the formulated inoculum as well as its quality.

In this mini-review, we analyze the immobilized-cell approach underlying the possibilities for its improvement and some specific characteristics of the carrier structure and formulation, particularly the role of additional compounds introduced into the cell-gel structures and the effect of the gel-forming polysaccharides and their derivates on plant health and growth.

\section{CELL-IMMOBILIZATION AS A TOOL FOR INOCULANT FORMULATION}

In bio-immobilization technology, water-soluble polymeric materials such as agar, methoxy-pectin, gellan gum, and mixtures of xanthan and locust bean gum, among many others, are largely used in the production of microbial-based products but alginate and carrageenan are the most used polymer-forming materials in microbial formulations to be introduced into soilplant systems (Bashan, 1998; Vassilev et al., 2001, 2005, 2014). The most frequently applied method of microbial cells/spores encapsulation uses the technique of interfacial polymerization.

There are a number of review papers describing in details the advantages and the "know-how" of the immobilization technology applied in formulation of plant beneficial microorganisms (Vassilev et al., 2001, 2005, 2014, 2015; Malusá et al., 2012; Bashan et al., 2016; Stamenkovic et al., 2018). Despite obvious benefits of immobilized-cell formulations of plant beneficial microorganisms having a controlled cell-release, their large-scale production and field application are still limited. One of the main reasons is the relatively high production cost (Vassilev et al., 2001; Chen et al., 2013; Bashan et al., 2016), since the cost of the polymeric carrier is higher than the other solid and liquid formulation components (John et al., 2011). Furthermore, the structure of a polymer carrier (e.g., that of alginate) is characterized by a low mechanical strength, which determines an unstable, uncontrolled release of its content. Cell mortality during the drying of encapsulated cells has also been recognized as a critical point of the bioencapsulation process (Cassidy et al., 1996; Bashan et al., 2002).

A future frontier in this field and one of the solutions of the above problems is the development of polymeric nanoparticle coatings (nano-formulations) or microencapsulated formulations. Microcapsules formulated by Wu et al. (2011) enhanced the survival rate of Klebsiella oxytoca Rs-5 under salinity stress. The cells released from microcapsules reached up to $10^{10} \mathrm{cfu} / \mathrm{g}$ when immersed in physiological saline solution for 3 weeks, improving cotton growth under high salinity conditions in pot experiments. However, there is the need to fully evaluate 
environmental and health safety issues before such technology could be implemented at industrial level (Kah, 2015).

Another possibility to develop a cost-effective encapsulated formulation is to find a low-cost gel carrier or gelling agent or partly replace the expensive polymer with lowcost additives. Nano-additives might enhance the stability of microbial-encapsulated products with respect to environmental conditions (e.g., desiccation, heat and UV inactivation) or provide substances needed by the inoculum and consequentially improve the shelf-life of these products or their delivery (Jampílek and Králová, 2017; Prasad et al., 2017). Table 1 illustrates the beneficial effects of some additives.

\section{THE ROLE OF ADDITIVES ON THE OVERALL PERFORMANCE OF IMMOBILIZED INOCULANTS}

\section{Clay Minerals}

There is a wide selection of additional materials used in bioimmobilized systems, which can serve as carrier bulking agents, enhance the formulation stability, protect and feed microbial cells or spores. Since the early studies on gel-entrapped soil microbial inoculants, polysaccharides/clay minerals combinations were used to protect the immobilized/encapsulated cells and to ensure their slow release into the environment (Marshall, 1968; Jung et al., 1982; van Elsas et al., 1992; Vassileva et al., 1999; Bashan et al., 2002). Clay minerals such as pyrophyllite have been experimented as bulking agents (Fravel et al., 1985) and bentonite and kaolin were used as fillers in alginate-glycerol immobilized Pantoea agglomerans and Trichoderma harzianum (Zohar-Perez et al., 2003). The freeze-dried alginate-bentonite and alginatekaolin combinations had a considerable positive effect on the bead's average wall thickness and significantly increased microbial survival reducing UV transmission compared to freecell and cells immobilized in alginate-glycerol without fillers.

The addition of bentonite to alginate-based formulation was found to increase the solid content and the porosity of alginate polymer used as a carrier of Raoultella planticola (He et al., 2015). Without bentonite, the release of the immobilized microbial cells was rapid in the first 3-day period followed by a constant cell release, while the presence of the additive regulated the continuous flow of the microorganism to the soil. Pseudomonas putida Rs-198 microencapsulated with a mix of alginate, bentonite and starch was reported to increase cotton biomass, soluble protein content, and chlorophylls a, b and carotenoid concentrations of cotton grown under saline conditions (He et al., 2017).

Liffourrena and Lucchesi (2018) applied perlite as filler of alginate microbeads formed in $\mathrm{CaCl}_{2}$ - paraffin emulsion mixture to formulate $P$. putida biostimulant. The number of cells reached $10^{8} \mathrm{CFU} / \mathrm{g}$ micro-beads and the increase in cell-gel mechanical stability was proportional to perlite concentration. This amount was sufficient to colonize Arabidopsis thaliana rhizosphere, with an increase in colonization over time from $2.1 \times 10^{4}$ to $9.2 \times 10^{5} \mathrm{CFU} / \mathrm{g}$ soil after 21 days.

\section{Skim Milk}

Skim milk is another additive widely used in bioformulations to enhance cell viability after storage (Yu et al., 2001). Bashan et al. (2002) found that the addition of skim milk powder to alginate-encapsulated Azospirillum brasilense significantly increased the cell number within the cell-bead structure. These beads degraded faster in soil than beads without skim milk thus releasing rapidly the entrapped cells into the soil-plant system. Alginate carrier with $10 \%$ skim milk significantly increased the numbers of Pseudomonas fluorescens cells released into the soil compared to combinations with soil extract and control beads

TABLE 1 | Examples of beneficial effect of additives on inoculant gel-based formulations.

\begin{tabular}{|c|c|c|c|}
\hline Microorganism & Additive & Beneficial effect & References \\
\hline $\begin{array}{l}\text { Pseudomonas cepacia; Talaromyces } \\
\text { flavus; Penicillium oxalicum; } \\
\text { Gliocladium virens; Trichoderma viride }\end{array}$ & Pyrophyllite & Bulking agent & Fravel et al., 1985 \\
\hline $\begin{array}{l}\text { Pantoea agglomerans; Trichoderma } \\
\text { harzianum }\end{array}$ & Chitin, kaolin or bentonite & Reduced UV transmition & Zohar-Perez et al., 2003 \\
\hline Raoultella planticola & Bentonite & Continuous cell release & He et al., 2015 \\
\hline P. putida & Perlite & Cell-gel stability & Liffourrena and Lucchesi, 2018 \\
\hline Azospirillum brasilense & Skim milk & Increased cell number in beads & Bashan et al., 2002 \\
\hline P. fluorescens & Skim milk & Increased cell number and soil; enhanced cell viability & Power et al., 2011 \\
\hline \multirow[t]{2}{*}{ Enterobacter sp. } & Skim milk & Better mycorrhization & Vassileva et al., 1999 \\
\hline & Skim milk and montmorillonite & Higher cell survival rate & Vassilev et al., 1997 \\
\hline Pseudomonas aeruginosa & Skim milk and clay minerals & Higher plant growth promotion & Cassidy et al., 1995 \\
\hline Fusarium oxysporum & Starch & High cell viability, shelf life, and soil colonization & Bailey et al., 1998 \\
\hline A. brasilense & Starch & Extended shelf life & Ivanova et al., 2005 \\
\hline Penicillium janthinellum & Chitin and dry dry olive wastes & Chitinase synthesis; biocontrol activity & Vassilev et al., 2008 \\
\hline Bacillus subtilis & Humic acids & Higher survival rate & Young et al., 2006 \\
\hline Raoultella terrigena & Trehalose & Desiccation protection & Schoebitz et al., 2013 \\
\hline Bacillus salmalaya & Protein hydrolysate & High encapsulation index & Vejan et al., 2018 \\
\hline
\end{tabular}


(Power et al., 2011). After 250 days of storage, 100\% recovery of viable cells was obtained from skim milk-alginate encapsulated P. fluorescens. Enterobacter sp. encapsulated in alginate gel enriched with $3 \%$ skim milk stimulated plant mycorrhization and demonstrated better bacterial establishment and phosphatesolubilizing activity in soil (Vassileva et al., 1999). This resulted in both higher growth of Lactuca sativa and higher number of cells released in the soil in comparison with plants inoculated with formulations without skim milk.

Designing complex formulations containing both skim milk and clay materials can be a strategy to increase the inoculum efficacy in comparison to single additives. Bentonite clay (3\% $\mathrm{w} / \mathrm{v}$ ) was found to increase the positive effect of skim milk powder $(3 \% \mathrm{w} / \mathrm{v})$ on the survival rate of $P$. fluorescens $\mathrm{R} 2 \mathrm{f}$ encapsulated in alginate (van Elsas et al., 1992). In another study, with laclux marked $P$. aeruginosa, a $1 \% \kappa$-carrageenan amended with skim milk and bentonite:montmorillonite (60:40\%) was more effective compared to alginate-skim milk formulation particularly after a 3-month storage of the dried beads (Cassidy et al., 1995). Vassilev et al. (1997) used skimmed milk and clay as additives to enhance metabolic activity in fermentation and soil conditions as well as the survival rate of the P-solubilizing Enterobacter sp. entrapped in agar beads.

\section{Starch}

Starch has been well studied in various biotechnological schemes with dried beads or liquid core capsules (Jankowski et al., 1997; Kim et al., 2005). It has successfully been used as a carrier or additive in formulations of plant beneficial microorganisms. In the bioencapsulation matrix, starch reduced the physical stress to microbial cells and significantly improved their survival (Bashan et al., 2002). Bacillus thuringiensis was entrapped in gelatinized corn starch (Shasha et al., 1984), which coupled with broad-band UV screens such as Congo red provided protection from solar radiation (Dunkle and Shasha, 1989). The effectiveness of this system in conidia formation per gram of mycelium was confirmed with the entomopathogenic fungi Metarhizium anisopliae and Beauveria bassiana (Pereira and Roberts, 1991). Complex formulations based on alginate-starch were used to formulate myco-herbicidal strains of Fusarium oxysporum (Bailey et al., 1998), which showed high viability/shelflife and rhizosphere colonization rate. Two endophytic fungi (Muscodor albus and Muscodor roseus) producing volatile mycofumigants were formulated in a mixture of water-absorbent starch, corn oil, sucrose, and fumed silica (Stinson et al., 2003). The produced formulations reduced the disease incidence of soilborne pathogens but plant growth reduction was observed probably due to the growth of deleterious rhizobacteria on some components of the complex carrier.

The protective effect of starch on the microbial cells under stress conditions is based on the cell adhesion to the starch. This process depends on the strain and the relationship between the adhesion to the starch and its use as a substrate (Crittenden et al., 2001). Furthermore, Tal et al. (1999) reported that the strength of an alginate-starch bead is directly proportional to its starch content and the distribution of starch granules within the beads is homogeneous at higher starch concentration. Even though the porosity of the beads' structure decreases with an increase in their starch content, the opposite tendency is observed after a period of storage when the porosity increases as the immobilized cells utilize the starch. The later phenomenon resulted in bacterial population levels of up to $10^{9} \mathrm{CFU} /$ bead in dry alginate-starch beads (Ivanova et al., 2005).

\section{Chitin and Chitosan}

Chitin and chitosan are oligosaccharides used in formulations as fillers or coating material, respectively. Chitosan is a bioactive polymer with a wide variety of functional properties such as antibacterial activity, non-toxicity, ease of modification, and biodegradability (Muxika et al., 2017). Addition of chitin or chitin-containing materials improved the multiplication of Bacillus subtilis and its fungicidal activity to control Fusarium wilt (Manjula and Podile, 2001). Chitin and dry olive wastes (DOW) were mixed with alginate to encapsulate Penicillium janthinellum (Vassilev et al., 2008). The fungus showed higher chitinase synthesis compared to alginate-entrapped mycelium, even when this was added singly with DOW or chitin. The three-component formulation induced P-solubilizing fungal activity while alginatechitin formulation exhibited biocontrol activity suppressing the soil-borne pathogen $F$. oxysporum. The use of chitin/chitosan to encapsulate microbes can also ease the storing and application on farms, which has been one of the major restriction to the use of biopesticides in recent times (John et al., 2011).

Chitosan is an excellent chelating agent, well known for its biocontrol activity against pathogens (Goy et al., 2009; Franco and Peter, 2011; Berger et al., 2014) and as elicitor enhances stress tolerance, antioxidant activity, and production of osmoregulators in plants (Dar et al., 2015). As a coating material, chitosan can lower the formulation cost, making the final product multifunctional due to its biocontrol and plant strengthening activities. The formulations can be produced by dropping alginate in a chitosan- $\mathrm{CaCl}_{2}$ solution or introducing already formed alginate beads into chitosan solution (Wittaya-Areekul et al., 2006).

Chitosan can also be an excellent carrier for plant beneficial microorganisms (Chanratana et al., 2018). Applying the methodology used for the development of a controlled-release fertilizer (Perez and Francois, 2016), where starch was added to a chitosan-based formulation as a filler, using a sodium tripolyphosphate aqueous solution as the crosslinking agent, A. brasilense and $P$. fluorescens were encapsulated in chitosanstarch formulation (Perez et al., 2018). The formulated bacteria survived at least 12 months at room temperature and humidity, maintaining a high viability $\left(10^{9} \mathrm{CFU}\right.$ of $A$. brasilense/g and $10^{8} \mathrm{CFU}$ of $P$. fluorescens/g). When introduced in soil, the bacterial cell number increased progressively during the first 20 days and then decreased.

\section{Humic Acids}

Humic products are known to promote or decrease the populations or activities of specific microbiome species (Pukalchik et al., 2019). Encapsulation of B. subtilis in alginate beads supplemented with humic acids ensured high viability of the immobilized biostimulant (Young et al., 2006). The 
immobilized gel-humic acid-cell system demonstrated excellent survival rate after storage for 5 months and slow cell release at various levels of $\mathrm{pH}$, providing also successful plant growth promotion by the encapsulated bacteria. The positive effect of this additive on plant growth can be explained considering its role as stimulant of the microbial growth and activity (Rekha et al., 2007) as well as for its effects on the physiology of plants (Nardi et al., 2002). The addition of humic acids in bacteria formulations could be also useful to promote root colonization by native mycorrhizal fungi (Gryndler et al., 2005).

\section{Sugars}

Sugars, such as sucrose, trehalose or glucose, are widely used to preserve microorganisms from changes in the osmotic pressure and can contribute to their conservation and maintenance particularly after drying (Morgan et al., 2006). However, combinations between sugars and sugars-additives have not been studied before and after the formulation of microbial-based products although various types of sugars and other additives (see previous paragraphs) usually improve the overall encapsulation efficacy. The addition of trehalose to the growth medium increased the survival of Raoultella terrigena during the drying process much more effectively protecting against desiccation than adding it to the matrix solution just prior to drying (Schoebitz et al., 2013). The complex formulation of B. bassiana based on the use of skimmed milk powder, polyvinylpyrrolidone K-90, and glucose was reported to achieve $100 \%$ conidial germination and $78 \%$ conidial viability, even after storage for 12 months at $30^{\circ} \mathrm{C}$ (Mishra et al., 2013).

\section{Protein Hydrolysates}

Protein hydrolysates derived from animal wastes and plant biomass after chemical, thermal and enzymatic hydrolysis, have been shown to enhance both nutrient uptake by plants and soil microbial activity (Colla et al., 2017; Casadesús et al., 2019). The latter was suggested to be the result of the stimulating presence of the organic molecules in protein hydrolysates, which serve as nutrients for the rhizospheric and phyllospheric microorganisms (Colla et al., 2017). Vegetable protein hydrolysates received more research interest particularly as co-polymers in microcapsules in the food, pharmaceutical and cosmetics industries (Nesterenko et al., 2013) but also in biostimulant production (Colla et al., 2015). In a recent work, B. salmalaya was encapsulated in chitosan-alginate-protein (brown rice) capsules, formulated in slurry or powder achieving an encapsulation index of 99.7 and $89.3 \%$, respectively (Vejan et al., 2018). Such result underlines the importance of additives based on vegetable proteins in future studies on formulation of biostimulants by gel-encapsulation.

\section{Glycerol, Silicon, Poly-Lactic Acid, and Strigolactones}

Some compounds with well-manifested functions advantageous to microorganisms could also be considered as potential additives. In a recent article we have analyzed the potential of glycerol, a trihydroxyalcohol widely used as a cell viability protector in strains' maintenance practice, in this respect and suggested the need for more studies on its application in formulation techniques (Vassilev et al., 2017). Similarly, silicon has not found wide applications as biostimulant to plants yet, particularly in encapsulated-cell formulations, although its benefits were widely reviewed (Savvas and Ntatsi, 2015). Trials using hydrophobic silica nanoparticles to the waterin-oil emulsion have shown an improvement in the delivery of the product, as well as an enhancement in shelf life by reduction of desiccation (Kaushik and Djiwanti, 2017). The use of new polymer-forming materials such as poly-lactic acid (PLA) could also open new possibilities to develop encapsulated inocula that would benefit of the physical characteristics of these compounds (Lai et al., 2009). Strigolactones (synthetic analogs), which communicate with the plant-microbiota systems, have been suggested as potential active additives (Vassilev et al., 2015) but as they demonstrate stimulating signals to parasitic plants and microorganisms (De Cuyper and Goormachtig, 2017), it would be challenging to develop an effective complex gelbased biostimulants.

\section{POTENTIAL EFFECT OF THE GEL-FORMING POLYSACCHARIDES ON PLANT HEALTH AND GROWTH}

Encapsulation of inoculant cells in polymers of polysaccharides such as alginate and carrageenan has been proposed long time ago as a technique to ensure controlled release of plant beneficial microorganisms into soil (Dommergues et al., 1979; Bashan, 1986). Surprisingly, few studies have examined simultaneously the fate of the gels in soil and the effect of the cell-free carriers on plants and rhizosphere microbiota. The positive effect on plants of seaweed crude extracts, the raw material from which several polysaccharides used for encapsulation technology derive, is based on the synergic action of growth regulators, osmolytes, polysaccharides and other algal compounds (Battacharyya et al., 2015). Seaweeds are known for their action as bioelicitors and particularly laminarin, carrageenan, and alginate, have been studied for their plant defense stimulating effects (Chandía et al., 2004; Khan et al., 2009; El Modafar et al., 2012; Vera et al., 2012; Zhang et al., 2015; Abouraicha et al., 2017; Ben Salah et al., 2018). There are strong evidences that polysaccharides play an important role in the mechanisms of abiotic stress protection for microorganisms (Vassilev et al., 2012). The production of alginate as exopolysaccharide increased in bacteria growing under drought conditions (Sa et al., 2019) creating a hydrated microenvironment contributing to biofilm architecture (Chang et al., 2007).

Particularly attractive for increasing plant growth and health are oligosaccharides derived from natural polysaccharides as they play the role of signal molecules regulating plant development and defense (Larskaya and Gorshkova, 2015). They can be obtained by enzymatic (Murata et al., 1993) and acidic depolymerization (Haug et al., 1966), and thermal polysaccharide treatment (Aida et al., 2010). Oligosaccharides produced by different methods demonstrated different physiological activities in animal cells (Iwamoto et al., 2005), but this phenomenon 
has not been widely studied on soil-plant-microbiota systems. A great part of studies on the plant growth promoting effect of oligosaccharides are performed after $\gamma$-irradiation of polysaccharides such as chitosan, $\kappa$-carrageenan and alginate. In this latter case, the effect of the resulting products on plants was higher when the irradiation was performed in solid-state compared to liquid solution (Hien et al., 2012). Oligochitosan, obtained after gamma-irradiation, was defined as a growth stimulator and anti-microbial agent for various plant systems (Muley et al., 2019a) including under conditions of drought stress (Muley et al., 2019b). Oligosaccharides (galacto-, isomalto-, fructo-, and xylo-) used as a part of alginate gel beads were reported to enhance cell viability of oral Lactobacillus fermentum and carrier stability when exposed to the specific environmental conditions (Liao et al., 2019). Similar inclusion of oligosaccharides should be expected in the near future in formulations of plant biostimulants. Other studies should be carried out on the behavior of the polysaccharide carriers in soil-plant systems, particularly to unravel in more details their degradation processes in soil by plants and/or microorganisms producing polysaccharide-cleaving enzymes. Such studies could help addressing the question on how the soil microbiota and plants are affected by the polysaccharide derivates, including oligosaccharides, composing the formulation of microbialbased products.

\section{CONCLUSION}

Significant progress has been made in developing formulations of plant beneficial microorganisms by entrapment in natural water-soluble polymer-based carriers and their application as biostimulants. However, published reports often do not consider or discuss the changes in the carrier characteristics by the entrapped cells or additives. There are indications that changed properties of polymers in presence of additives positively affect their ability to maintain and protect the microorganisms. Moreover, in many cases the additives potentially affect plant growth and health and simultaneously

\section{REFERENCES}

Abouraicha, E., El Alaoui-Talibi, Z., Tadlaoui-Ouafi, A., El Boutachfaiti, R., Petit, E., Douira, A., et al. (2017). Glucuronan and oligoglucuronans isolated from green algae activate natural defense responses in apple fruit and reduce postharvest blue and gray mold decay. J. Appl. Phycol. 29, 471-480. doi: 10.1007/s10811016-0926-920

Adholeya, A., and Das, M. (2012). "Biofertilizers: potential for crop improvement under stressed conditions," in Improving Crop Productivity In Sustainable Agriculture, ed. N. Tuteja, (Weinheim: Wiley-VCH), 183-200. doi: 10.1002/ 9783527665334.ch9

Ahmad, M., Pataczek, L., Hilger, T. H., Zahir, Z. A., Hussain, A., Raschev, F., et al. (2018). Perspectives of microbial inoculation for sustainable development and environmental management. Front. Microbiol. 9:2992. doi: 10.3389/fmicb.2018. 02992

Aida, T. M., Yamagata, T., Watanabe, M., and Smith, R. L. (2010). Depolymerization of sodium alginate under hydrothermal conditions. Carbohydr. Polym. 80, 296-302. doi: 10.1016/j.carbpol.2009.11.032 induce microorganisms to release metabolites thus provoking changes in the typical gel structure and integrity. The resulting microbial and gel side-products might stimulate plant growth and exert biocontrol activity. In some cases, it has been shown that additives are exerting a negative effect on the whole cell encapsulation system. Manitol was reported to decrease germination of gel-encapsulated spores (Liu et al., 2015). Viveganandan and Jauhri (2000) found that charcoal-soil, mixed with alginate, adversely affected the loading and survival of phosphate-solubilizing bacteria. Therefore, a deeper analysis of the relationship carriers-additives-microorganisms-soil-plant systems can provide important information that is essential to understand the functional characteristics of immobilized biostimulants and determine strategies for their application. Research efforts should also be oriented toward development of micro-environmental conditions to facilitate the growth and functional activity of the bioformulates, including in the carriers specific prebiotic compounds. As we repeatedly pointed out, research scientists working with immobilization methods should use techniques already proven in other biotechnological fields. Further improvement of immobilized cell methodologies should be based on multidisciplinary research of wide number of experts in microbiology, plant physiology/pathology, formulation specialists and agricultural engineers in order to provide efficient, safe, economically acceptable, and easy to apply complex biotechnological products for plant growth and health.

\section{AUTHOR CONTRIBUTIONS}

NV and MV designed and drafted the work. EM, LG, VM, JK, and $\mathrm{BT}$ contributed to the revision of the manuscript.

\section{FUNDING}

This work was supported by the project EXCALIBUR funded from the European Union's Horizon 2020 Research and Innovation Program under grant agreement No. 817946.

Arora, N. K., and Mishra, J. (2016). Prospecting the roles of metabolites and additives in future bioformulations for sustainable agriculture. Appl. Soil Ecol. 107, 405-407. doi: 10.1016/j.apsoil.2016.05.020

Aydi-Ben Abdallah, R., Hassine, M., Jabnoun-Khiareddine, H., Haouala R., and Daami-Remadi, M. (2014). Antifungal activity of culture filtrates and organic extracts of Aspergillus spp. against Pythium ultimum Tunisian. J. Plant Prot. 9, $17-30$.

Baez-Rogelio, A., Morales-Garcia, Y. E., Quintero-Hernandez, V., and MuñosRojas, J. (2017). Next generation of microbial inoculants for agriculture and bioremediation. Microb. Biotechnol. 10, 19-21. doi: 10.1111/1751-7915.12448

Bailey, B. A., Hebbar, K. P., Strem, M., and Lumsden, R. D. (1998). Formulations of Fusarium oxysporum f.sp. erythroxyli for biocontrol of Erythroxylum coca var. coca. Weed Sci. 46, 682-689.

Bashan, Y. (1986). Significance of timing and level of inoculation with rhizosphere bacteria on wheat plants. Soil Biol. Biochem. 18, 297-301. doi: 10.1016/00380717(86)90064-90067

Bashan, Y. (1998). Inoculants of plant growth-promoting bacteria for use in agriculture. Biotechnol. Adv. 16, 729-770. doi: 10.1016/S0734-9750(98)00003-2 
Bashan, Y., de-Bashan, L. E., and Prabhu, S. R. (2016). "Superior polymeric formulations and emerging innovative products of bacterial inoculants for sustainable agricultura and the environment," in Agriculturally Important Microorganisms - Commercialization and Regulatory Requirements in Asia. eds H. B. Singh, B. K.Sarma, C. Keswani (Berlin: Springer), 15-46. doi: 10.1007/ 978-981-10-2576-1_2

Bashan, Y., de-Bashan, L. E., Prabhu, S. R., and Hernandez, J-P. (2014). Advances in plant growth-promoting bacterial inoculant technology: formulations and practical perspectives (1998-2013). Plant Soil 378:1-33. doi: 10.1007/s11104013-1956-X

Bashan, Y., Hernandez, J. P., Leyva, L. A., and Bacilio, M. (2002). Alginate microbeads as inoculant carriers for plant growth-promoting bacteria. Biol. Fertil. Soils 35, 359-368. doi: 10.1007/s00374-002-0481-485

Battacharyya, D., Babgohari, M. Z., Rathor, P., and Prithiviraj, B. (2015). Seaweed extracts as biostimulants in horticulture. Sci. Hortic. 196, 39-48. doi: 10.1016/j. scienta.2015.09.012

Ben Salah, I., Aghrouss, S., Douira, A., Aissam, S., El Alaoui-Talibi, Z., FilaliMaltouf, A., et al. (2018). Seaweed polysaccharides as bio-elicitors of natural defenses in olive trees against verticillium wilt of olive. J. Plant Interact. 13, 248-255. doi: 10.1080/17429145.2018.1471528

Berg, G. (2009). Plant-microbe interactions promoting plant growth and health: perspectives for controlled use of microorganisms in agriculture. Appl. Microbiol. Biotechnol. 84, 11-18. doi: 10.1007/s00253-009-2092-7

Berger, L. R. R., Stamford, T. C. M., Stamford-Arnoud, T. M., Alcântara, S. R. C., Silva, A. C., Silva, A. M., et al. (2014). Green conversion of agroindustrial wastes into chitin and chitosan by Rhizopus arrhizus and Cunninghamella elegans strain. Molecules 15, 9082-9102. doi: 10.3390/ijms1505 9082

Bhattacharyya, P. N., and Jha, D. K. (2012). Plant growth-promoting rhizobacteria (PGPR): emergence in agriculture. World J. Microbiol. Biotechnol. 28, 13271350. doi: 10.1007/s11274-011-0979-9

Casadesús, A., Polo, J., and Munné-Bosch, S. (2019). Hormonal effects of an enzymatically hydrolyzed animal protein-based biostimulant (Pepton) in water-stressed tomato plants. Front. Plant Sci. 10:758. doi: 10.3389/fpls.2019. 00758

Cassidy, M. B., Lee, H., and Trevors, J. T. (1996). Environmental applications of immobilized microbial cells: a review. J. Ind. Microbiol. 16, 79-101. doi: 10.1007/BF01570068

Cassidy, M. B., Leung, K. T., Lee, H., and Trevors, J. T. (1995). Survival of lac-lux marked Pseudomonas aeruginosa UG2Lr cells encapsulated in k-carrageenan and alginate. J. Microbiol. Methods 23, 281-290. doi: 10.1016/0167-7012(95) 00038-M

Catroux, G., Hartmann, A., and Revellin, C. (2001). Trends in rhizobial inoculant production and use. Plant Soil 230, 21-30. doi: 10.1023/A:1004777115628

Chandía, N. P., Matsuhiro, B., Mejías, E., and Moenne, A. (2004). Alginic acids in Lessonia vadosa: partial hydrolysis and elicitor properties of the polymannuronic acid fraction. J. Appl. Phycol. 16, 127-133. doi: 10.1023/B:JAPH. 0000044778.44193.a8

Chang, W. -S., van de Mortel, M., Nielsen L., Nino de Guzman, G., Li, X., and Halverson, L. J. (2007). Alginate production by Pseudomonas putida creates a hydrated microenvironment and contributes to biofilm architecture and stress tolerance under water-limiting conditions. J. Bacteriol. 189, 8290-8299. doi: 10.1128/JB.00727-07

Chanratana, M., Han, G. H., Joe, M. M., Choudhury, A. R., Sundaram, S., and Abdul Halim, MD et al. (2018). Evaluation of chitosan and alginate immobilized Methylobacterium oryzae CBMB20 on tomato plant growth. Arch. Agron. Soil Sci. 64, 1489-1502. doi: 10.1080/03650340.2018.1440390

Chen, K. N., Chen, C. Y., Lyn, Y. C., and Chen, M. J. (2013). Formulation of a novel antagonistic bacterium based biopesticide for fungal disease using microencapsulation techniques. J. Agric. Sci. 5, 153-163. doi: 10.5539/jas. v5n3p153

Colla, G., Hoagland, L., Ruzzi, M., Cardarelli, M., Bonini, P., Canaguier, R., et al. (2017). Biostimulant action of protein hydrolysates: unraveling their effects on plant physiology and microbiome. Front. Plant Sci. 8:2202. doi: 10.3389/fpls. 2017.02202

Colla, G., Nardi, S., Cardarelli, M., Ertani, A., Lucini, L., Canaguier, R., et al. (2015). Protein hydrolysates as biostimulants in horticulture. Sci. Hortic. 196, 28-38. doi: 10.1016/j.scienta.2015.08.037
Crittenden, R., Laitila, A., Forssell, P., Mättö, J., Saarela, M., Mattila-Sandholm, T., et al. (2001). Adhesion of bifidobacteria to granular starch and its implications in probiotic technologies. Appl. Environ. Microbiol. 67, 3469-3475. doi: 10. 1128/aem.67.8.3469-3475.2001

Dar, T. A., Uddin, M., Khan, M. M., Ali, A., Mir, S. A., and Varshney, L. (2015). Effect of Co-60 gamma irradiated chitosan and phosphorus fertilizer on growth, yield and trigonelline content of Trigonella foenum-graecum L. J. Radiat. Res. Appl. Sci. 8, 446-458. doi: 10.1016/j.jrras.2015.03.008

De Cuyper, C., and Goormachtig, S. (2017). Strigolactones in the rhizosphere: friend or foe? MPMI 30, 683-690. doi: 10.1094/MPMI-02-17-0051-CR

Dommergues, Y. R., Diem, H. G., and Divies, C. (1979). Polyacrylamide-entrapped rhizobium as an inoculant for legumes. Appl. Environ. Microbiol. 37, 779-781. doi: 10.1128/aem.37.4.779-781.1979

Dunkle, R. L., and Shasha, B. S. (1989). Response of starch-encapsulated Bacillus thuringiensis containing ultraviolet screens to sunlight. Environ. Entom. 18, 1035-1041. doi: 10.1093/ee/18.6.1035

El Modafar, C., Elgadda, M., El Boutachfaiti, R., Abouraicha, E., Zehhar, N., Petit, E., et al. (2012). Induction of natural defence accompanied by salicylic aciddependant systemic acquired resistance in tomato seedlings in response to bio-elicitors isolated from green algae. Sci. Hortic. 138, 55-63. doi: 10.1016/j. scienta.2012.02.011

Franco, T. T., and Peter, M. G. (2011). Advances in chitin and chitosan research. Polym. Intern. 60, 873-969. doi: 10.1002/pi.3111

Fravel, D. R., Marois, J. J., Lumsden, R. D., and Connick, W. J. Jr. (1985). Encapsulation of potential biocontrol agents in an alginate-clay matrix. Phytopathology 75, 774-777. doi: 10.1094/Phyto-75-774

Goy, R., De Britto, D., and Assis, O. B. G. (2009). A review of the antimicrobial activity of chitosan. Polímeros 19, 241-242. doi: 10.1590/S010414282009000300013

Gryndler, M., Larsen, J., Hrselova, H., Rezacova, V., Gryndlerova, H., and Kubat, J. (2005). Organic and mineral fertilization, respectively, increase and decrease the development of external mycelium of arbuscular mycorrhizal fungi in a longterm field experiment. Mycorrhiza 16, 159-166. doi: 10.1007/s00572-005-002724

Haug, A., Larsen, B., and Smidsrod, O. (1966). A study of the constitution of alginic acid by partial acid hydrolysis. Acta Chem. Scand. 20, 183-190. doi: 10.3891/acta.chem.scand.20-0183

He, Y., Wu, Z., Tu, L., Han, Y., Znahg, G., and Li, C. (2015). Encapsulation and characterization of slow-release microbial fertilizer from the composites of bentonite and alginate. Appl. Clay Sci. 109-110, 68-75. doi: 10.1016/j.clay.2015. 02.001

He, Y., Wu, Z., Tu, L., and Shan, C. (2017). Effect of encapsulated Pseudomonas putida Rs-198 strain on alleviating salt stress of cotton. J. Plant Nutr. 40, 1180-1189. doi: 10.1080/01904167.2016.1264595

Herrmann, L., and Lesueur, D. (2013). Challenges of formulation and quality of biofertilizers for successful inoculation. Appl. Microbiol. Biotechnol. 97, 8859-8873. doi: 10.1007/s00253-013-5228-8

Hien, N. Q., Nagasawa, N., Tham, L. X., Yoshii, F., Dang, V. H., Mitomo, H., et al. (2012). Growth-promotion of plants with depolymerized alginates by irradiation. Radiat. Phys. Chem. 59, 97-101. doi: 10.1016/S0969-806X(99) 00522-528

Ivanova, E., Teunou, E., and Poncelet, D. (2005). “Alginate based macrocapules as inoculants carriers for production of nitrogen biofertilisers," in Proceedings of the Balkan scientific conference of Biology, Plovdiv, 90-108.

Iwamoto, M., Kurachi, M., Nakashima, T., Kim, D., Yamaguchi, K., Oda, T., et al. (2005). Structure-activity relationship of alginate oligosaccharides in the induction of cytokine production from RAW264.7 cells. FEBS Lett. 579, 4423-4429. doi: 10.1016/j.febslet.2005.07.007

Jampílek, J., and Králová, K. (2017). "Nanomaterials for delivery of nutrients and growth-promoting compounds to plants," in Nanotechnology: An Agricultural Paradigm, eds R. Prasad, M. Kumar, and V. Kumar (Singapore: Springer), 177-226. doi: 10.1007/978-981-10-4573-8_9

Jankowski, T., Zielinska, M., and Wysakowska, A. (1997). Encapsulation of lactic acid bacteria with alginate/starch capsules. Biotechnol. Tech. 11, 31-34. doi: 10.1007/BF02764447

John, R. P., Tyagi, R. D., Brar, S. K., Surmpalli, R. Y., and Prevost, D. (2011). Bio-encapsulation of microbial cells for target agricultural delivery. Crit. Rev. Biotechnol. 31, 211-226. doi: 10.3109/07388551.2010.513327 
Jung, G., Mugnier, J., Diem, H. G., and Domerguez, Y. R. (1982). Polymerentrapped rhizobium as an inoculant for legumes. Plant Soil 65, 219-231. doi: $10.1007 /$ BF02374652

Kah, M. (2015). Nanopesticides and nanofertilizers: emerging contaminants or opportunities for risk mitigation? Front. Chem. 3:64 doi: 10.3389/fchem.2015. 00064

Kaushik, S., and Djiwanti, S.R. (2017). Nanotechnology for enhancing crop productivity, In Nanotechnology: An Agricultural Paradigm, eds R. Prasad, and M. V. Kumar (Singapore: Springer), 249-262. doi: 10.1007/978-981-10-45738_11

Khan, W., Rayirath, U. P., Subramanian, S., Jithesh, M. N., Rayorath, P., Hodges, D. M., et al. (2009). Seaweed extract as biostimulants of plant growth and development. J. Plant Growth Regul. 28, 386-399 doi: 10.1007/s00344-0099103-X

Kim, Y. J., Park, H. G., Yang, Y. L., Yoon, Y., Kim, S., and Oh, E. (2005). Multifunctional drug delivery system using starch-alginate beads for controlled release. Biol. Pharm. Bull. 28, 394-397. doi: 10.1248/bpb.28.394

Kumar, V., Rajauria, G., Sahai, V., and Bisaria, V. S. (2012). Culture filtrate of root endophytic fungus Piriformospora indica promotes the growth and lignan production of Linum album hairy root cultures. Proc. Biochem. 47, 901-907. doi: 10.1016/j.procbio.2011.06.012

Lai, Z., Cui, Y., Gao, P., and Chen, X. (2009). Modified PLA carrier material and its performance in immobilization of nitrifying bacteria. Mater. Sci. Forum 610-613, 198-201. doi: 10.4028/www.scientific.net/msf.610-613.198

Larskaya, I. A., and Gorshkova, T. A. (2015). Plant oligosaccharides - Outsiders among elicitors? Biochemistry, 80, 881-900. doi: 10.1134/S0006297915070081

Liao, N., Luo, B., Gao, J., Li, X., Zhao, Z., Zhang, Y., et al. (2019). Oligosaccharides as co-encapsulating agents: effect on oral Lactobacillus fermentum survival in a simulated gastrointestinal tract. Biotechol. Lett. 41, 263-272. doi: 10.1007/ s10529-018-02634-2636

Liffourrena, A. S., and Lucchesi, G. I. (2018). Alginate-perlite encapsulated Pseudomonas putida A (ATCC 12633) cells: preparation, characterization and potential use as plant inoculants. J. Biotechnol. 278, 28-33. doi: 10.1016/j.jbiotec. 2018.04.019

Liu, H., Zhao, X., Guo, M., Liu, H., and Zheng, Z. (2015). Growth and metabolism of Beauveria bassiana spores and mycelia. BMC Microbiol. 15:267 doi: 10.1186/ s12866-015-0592-594?

Malusá, E., Paszt, L. S., and Ciesielska, J. (2012). Technologies for beneficial microorganisms inocula used as biofertilizers. Sci. World J. 2012, 1-12. doi: $10.1100 / 2012 / 491206$

Malusá, E., Pinzari, F., and Canfora, L. (2016). "Efficacy of biofertilizers: challenges to improve crop production," in Microbial Inoculants in Sustainable Agricultural Productivity - Vol. 2, eds D. Singh, H. Singh, and R. Prabha (Berlin Springer), 17-40. doi: 10.1007/978-81-322-2644-4_2

Malusá, E., and Vassilev, N. (2014). A contribution to set a legal framework for biofertilisers. Appl. Microbiol. Biotechnol. 98, 6599-6607. doi: 10.1007/s00253014-5828-y

Manjula, K., and Podile, A. R. (2001). Chitin supplemented formulations improve biocontrol and plant growth-promoting efficiency of Bacillus subtilis AF1. Can. J. Microbiol. 47:618-625. doi: 10.1139/w01-057

Maron, P. A., Sarr, A., Kaisermann, A., Leveque, J., Mathieu, O., Guigue, J., et al. (2018). High microbial diversity promotes soil ecosystem functioning. Appl. Environ. Microbiology 84:e002738-17. doi: 10.1128/AEM.02738-2717

Marshall, K. C. (1968). Interaction between colloidal montmorillonite and cells of Rhizobium species with different inogenic surfaces. Biochim. Biophys. Acta 156, 179-186. doi: 10.1016/0304-4165(68)90117-90117

Mendes, G., Galvez, A., Vassileva, M., and Vassilev, N. (2017). Fermentation liquid containing microbially solubilized $\mathrm{P}$ significantly improved plant growth and P uptake in both soil and soilless experiments. Appl. Soil Ecol. 117, 208-211. doi: 10.1016/j.apsoil.2017.05.008

Mendes, G. O., Silva, N. M. R. M., Anastacio, T. C., Vassilev, N. B., Ribeiro, J. I., Silva, I. R., et al. (2015). Optimization of Aspergillus niger rock phosphate solubilization in solid-state fermentation and use of the resulting product as a P fertilizer. Microb. Biotechnol. 8, 930-939. doi: 10.1111/1751-7915.12289

Mishra, S., Kumar, P., and Malik, A. (2013). Preparation, characterization, and insecticidal activity evaluation of three different formulations of Beauveria bassiana against Musca domestica . Parasitol. Res. 112, 3485-3495 doi: 10.1007/ s00436-013-3529-3526
Morgan, C. A., Herman, N., White, P. A., and Vessey, G. (2006). Preservation of microorganisms by drying. A review. J. Microbiol. Methods 66, 183-193. doi: 10.1016/j.mimet.2006.02.017

Muley, A. B., Ladole, M. R., Suprasanna, P., and Dalvi, S. G. (2019a). Intensification in biological properties of chitosan after $\gamma$-irradiation. Int. J. Biol. Macromol. 131, 435-444. doi: 10.1016/j.ijbiomac.2019.03.072

Muley, A. B., Shingote, P. R., Patil, A. P., Dalvi, S. G., and Suprasanna, P. (2019b). Gamma radiation degradation of chitosan for application in growth promotion and induction of stress tolerance in potato (Solanum tuberosum L.). Carbohydr. Polym. 210, 289-301. doi: 10.1016/j.carbpol.2019.01.056

Murata, K., Inose, T., Hisano, T., Abe, S., Yonemoto, Y., Yamashita, T., et al. (1993). Bacterial alginate lyase - Enzymology, genetics and application. J. Ferm. Bioeng. 76, 427-437. doi: 10.1016/0922-338X(93)90040-F

Muxika, A., Etxabide, A., Uranga, J., Guerrero, P., and de la Caba, K. (2017). Chitosan as a bioactive polymer: processing, properties and applications. Int. J. Biol. Macromol. 105, 1358-1368. doi: 10.1016/j.ijbiomac.2017.07.087

Nardi, S., Pizzeghello, D., Muscolo, A., and Vianello, A. (2002). Physiological effects of humic substances on higher plants. Soil Biol. Biochem. 34, 1527-1536. doi: 10.1016/S0038-0717(02)00174-178

Nesterenko, A., Alric, I., Silvestre, F., and Durrieu, V. (2013). Vegetable proteins in microencapsulation: a review of recent interventions and their effectiveness. Ind. Crops Prod. 42, 469-479. doi: 10.1016/j.indcrop.2012.06.035

Pereira, R. M., and Roberts, A. W. (1991). Alginate and corn starch mycelial formulations of entomopathogenic fungi Beauveria bassiana and Metarhizium anisopliae. J. Econ. Entomol. 84, 1657-1661. doi: 10.1093/jee/84.6.1657

Perez, J. J., and Francois, N. J. (2016). Chitosan-starch beads prepared by ionotropic gelation as potential matrices for controlled release of fertilizers. Carbohydr. Polym. 148, 134-142. doi: 10.1016/j.carbpol.2016.04.054

Perez, J. J., Francois, N. J., Maroniche, G. A., Borrajo, M. P., Pereyra, M. A., and Creus, C. M. (2018). A novel, green, low-cost chitosan-starch hydrogel as potential delivery system for plant growth-promoting bacteria. Carbohydr. Polym. 202, 409-417. doi: 10.1016/j.carbpol.2018.07.084

Power, B., Liu, X., Germaine, K. J., Ryan, D., Brazil, D., and Dowling, D. N. (2011). Alginate beads as a storage delivery and containment system for genetically modified PCB degrader and PCB biosensor derivates of Pseudomonas fluorescens F113. J. Appl. Microbiol. 110, 1351-1358. doi: 10.1111/j.1365-2672. 2011.04993.x

Prasad, R., Bhattacharyya, A., and Nguyen, Q. D. (2017). Nanotechnology in sustainable agriculture: recent developments, challenges, and perspectives. Front. Microbiol. 8:1014. doi: 10.3389/fmicb.2017.01014

Pukalchik, M., Kydralieva, K., Yakimenko, O., Fedoseeva, E., and Terekhova, V. (2019). Outlining the potential role of humic products in modifying biological properties of the soil-a review. Front. Environ. Sci. 7:80. doi: 10.3389/fenvs. 2019.00080

Rekha, P. D., Lai, W. A., Arun, A. B., and Young, C. C. (2007). Effect of free and encapsulated Pseudomonas putida CC-FR2-4 and Bacillus subtilis CC-pg104 on plant growth under gnotobiotic conditions. Bioresour. Technol. 98, 447-451. doi: 10.1016/j.biortech.2006.01.009

Sa, C., Cardosos, P., and Figueira, E. (2019). Alginate as a feature of osmotolerance differentiation among soil bacteria isolated from wild legumes growing in Portugal. Sci. Total Environ. 681, 312-319. doi: 10.1016/j.scitotenv.2019. 05.050

Sahu, P. K., and Brahmaprakash, G. P. (2016). "Formulations of biofertilizers approaches and advances," in Microbial Inoculants in Sustainable Agricultural Productivity Vol. 2: Functional Applications, eds D. Singh, H. Singh, and R. Prabha (Berlin: Springer), 179-198. doi: 10.1007/978-81-322-2644-4_12

Savvas, D., and Ntatsi, G. (2015). Biostimulant activity of silicon in horticulture. Sci. Hortic. 196, 66-81. doi: 10.1016/j.scienta.2015.09.010

Schoebitz, M., López, M., and Roldán, A. (2013). Bioencapsulation of microbial inoculants for better soil-plant fertilization. A review. Agron. Sustain. Dev. 33 (4): 751-765. doi: 10.1007/s13593-013-0142-140

Shasha, B. S., Trimnell, D., and Oley F. H. (1984). Starch borate complexes for EPTC encapsulation. J. Appl. Polym. Sci. 29, 67-73. doi: 10.1002/app.1984. 070290107

Shilev, S., Azaizeh, H., Vassilev, N., Georgiev, D., Babrikova, I. (2019). "Interactions in soil-microbe-plant system: adaptation to stressed agriculture," in Microbial Interventions in Agriculture and Environment, eds D. Singh, V. Gupta, and R. Prabha (Singapore: Springer), 131-171. doi: 10.1007/978-981-13-8391-5_6 
Stamenkovic, S., Beskoski, V., Karabegovic, I., Lazic, M., and Nikolic, N. (2018). Microbial fertilizers: a comprehensive review on current findings and future perspectives. Span. J. Agr. Res. 16:e09R01. doi: 10.5424/sjar/2018161-2012117

Stephens, J. H. G., and Rask, H. M. (2000). Inoculant production and formulation. Field Crops Res. 65:249-258 doi: 10.1016/s0378-4290(99)00090-8

Stinson, A. M., Zidack, N. K., Strobel, G. A., and Jacobsen, B. J. (2003). Mycofumigation with Muscodor albus and Muscodor roseus for control of seedling diseases of sugar beet and Verticillium wilt of eggplant. Plant Dis. 87, 1349-1354. 10.1094/PDIS.2003.87.11.1349 doi: 10.1094/pdis.2003.87.11.1349

Tal, Y., van Rijn, J., and Nusinuvitch, A. (1999). Improvement of mechanical and biological properties of freeze-dried denitrifying alginate beads by using starch as a filler and carbon source. Appl. Microbiol. Biotechnol. 51, 773-779. doi: $10.1007 / \mathrm{s} 002530051461$

Thrane, C., Tronsmo, A., and Jensen, D. F. (1997). Endo-1, 3-b-glucanase and cellulose from Trichoderma harzianum: purification and partial characterization, induction by and biological activity against plant pathogenic Pythium spp. Eur. J. Plant Pathol. 103, 331-344. doi: 10.1023/A:1008679319544

van der Heijden, M. G. A., Bardgett, R. D., van Straalen, N. M. (2008). The unseen majority: soil microbes as drivers of plant diversity and productivity in terrestrial ecosystems. Ecol. Lett. 11, 296-310. doi: 10.1111/j.1461-0248.2007. 01139.x

van Elsas, J. D., Trevors, J. T., Jain, D., Wolters, A. C., Heijnen, C. E., and van Overbeek, L. S. (1992). Survival of and root colonization by, alginateencapsulated Pseudomonas fluorescens cells following introduction into soil. Biol. Fertil. Soils 14, 14-22. doi: 10.1007/BF00336297

Vassilev, N., Eichler-Löbermann, B., Flor-Peregrin, E., Martos, V., Reyes, A., and Vassileva, M. (2017). Production of a potential liquid plant bio-stimulant by immobilized Piriformospora indica in repeated-batch fermentation process. AMB Express 7:106. doi: 10.1186/s13568-017-0408-z

Vassilev, N., Eichler-Lobermann, B., and Vassileva, M. (2012). Stress tolerant P-solubilizing microorganisms. Appl. Microbiol. Biotechnol. 95, 851-859. doi 10.1007/s00253-012-4224-4228 doi: 10.1007/s00253-012-4224-8

Vassilev, N., and Mendes, G. (2018). "Solid-state fermentation and plant beneficial microorganisms," in Current Developments in Biotechnology and Bioengineering, Current Advances in Solid-State Fermentation, eds A. Pandey, C. H. Larroche, and C. Soccol (Amsterdam: Elsevier), 402-416.

Vassilev, N., Mendes, G., Costa, M., and Vassileva, M. (2014). Biotechnological tools for enhancing microbial solubilization of insoluble inorganic phosphates. Geomicrobiol. J. 31, 751-763. doi: 10.1080/01490451.2013.822615

Vassilev, N., Nikolaeva, I., and Vassileva, M. (2005). Polymer-based preparation of soil inoculants: applications to arbuscular mycorrhizal fungi. Rev. Environ. Sci. Bio. Technol. 4, 235-243. doi: 10.1007/s11157-005-2098-2092

Vassilev, N., Requena, A., Nieto, L., Nikolaeva, I., and Vassileva, M. (2009). Production of manganese peroxidase by Phanerochaete chrysosporium grown on medium containing agro-wastes/rock phosphate and bio-control properties of the final product. Ind. Crops Prod. 30, 28-32. doi: 10.1016/j.indcrop.2009.01. 001

Vassilev, N., Reyes, A., Garcia, M., Vassileva, M (2008). "Production of chitinase by free and immobilized cells of Penicillium janthinellum. A comparison between two biotechnological schemes for inoculant formulation," in Proceedings of the XVIth International Conference on Bioencapsulation, Dublin, 1-4.

Vassilev, N., Toro, M., Vassileva, M., Azcon, R., and Barea, J.M. (1997). Rock phosphate solubilization by immobilized cells of Enterobacter sp. In fermentation and soil conditions. Bioresour. Technol. 61, 29-32. doi: 10.1016/ S0960-8524(97)84694-9

Vassilev, N., Vassileva, M., Fenice, M., and Federici, F. (2001). Immobilized cell technology applied in solubilization of insoluble inorganic (rock) phosphates and P plant acquisition. Bioresour. Technol 79, 263-271. doi: 10.1016/s09608524(01)00017-7
Vassilev, N., Vassileva, M., Lopez, D., Martos, V., Reyes, A., Maksimivich, I., Eichler-Löbermann, B., and Malusa, E. (2015). Unexploited potential of some biotechnological techniques for biofertilizer production and formulation. Appl. Microbiol. Biotechnol. 99, 4983-4996. doi: 10.1007/s00253-015-6656-6654

Vassileva, M., Azcon, R., Barea, J. M., and Vassilev, N. (1999). Effect of encapsulated cells of Enterobacter sp. on plant growth and phosphate uptake. Bioresour. Technol. 67, 229-232. doi: 10.1016/S0960-8524(98)00130-138

Vassileva M., Serrano M., Bravo V., Jurado E., Nikolaeva I., Martos V., Vassilev N. (2010). Multifunctional properties of phosphate-solubilizing microorganisms grown on agro- industrial wastes in fermentation and soil conditions. Appl. Microbiol. Biotechnol. 85, 1287-1299. doi: 10.1007/s00253-009-2366-2360

Vejan, P., Abdullah, R., Khadiran, T., and Ismail, S. (2018). Encapsulation of Bacillus salmalaya 139SI using double coating bio-polymer technique. Lett. Appl. Microbiol. 68, 56-63. doi: 10.1111/lam.13088

Vera, J., Castro, J., Contreras, R. A., González, A., and Moenne, A. (2012). Oligocarrageenans induce a long-term and broad-range protection against pathogens in tobacco plants (var. Xanthi). Physiol. Mol. Plant Pathol. 79, 31-39. doi: 10.1016/j.pmpp.2012.03.005

Vinale, F., Manganiello, G., Nigro, M., Mazzei, P., Piccolo, A., Pascale, A., et al. (2014). A novel fungal metabolite with beneficial properties for agricultural applications. Molecules 19, 9760-9772. doi: 10.3390/molecules190 79760

Viveganandan, G., and Jauhri, K. S. (2000). Growth and survival ofphosphate solubilizing bacteria in calcium alginate. Microbiol. Res. 155, 205-207. doi: 10.1016/S0944-5013(00)80033-80036

Wittaya-Areekul, S., Kruenate, J., and Prahsarn, C. (2006). Preparation and in vitro evaluation of mucoadhesive properties of alginate/chitosan microparticles containing prednisolone. Int. J. Pharm. 312, 113-118. doi: 10.1016/j.ijpharm. 2006.01.003

Wu, Z., Zhao, Y., Kaleem, I., and Li, C. (2011). Preparation of calcium-alginate microcapsuled microbial fertilizer coating Klebsiella oxytoca Rs-5 and its performance under salinity stress. Eur. J. Soil Biol. 47, 152-159. doi: 10.1016/ j.ejsobi.2010.11.008

Young, C. C., Rekha, P. D., Lai, W. A., and Arun, A. B. (2006). Bioencapsulation of plant growth promoting bacteria in alginate beads enriched with humic acid. Biotechnol. Bioeng. 1, 76-83. doi: 10.1002/bit.20957

Yu, W. K., Yim, T. B., Lee, K. Y., and Heo, T. R. (2001). Effect of skim milk-alginate beads on survival rate of Bifidobacteria. Biotechnol. Bioprocess Eng. 6, 133-138. doi: 10.1007/BF02931959

Zhang, S., Tang, W., Jiang, L., Hou, Y., Yang, F., Chen, W., et al. (2015). Elicitor activity of algino-oligosaccharide and its potential application in protection of rice plant (Oryza saliva L.) against Magnaporthe grisea. Biotechnol. Biotechnol. Equ. 29, 646-652. doi: 10.1080/13102818.2015.1039943

Zohar-Perez, C., Chernin, L., Chet, I., and Nussinovitch, A. (2003). Structure of dried cellular alginate matrix containing fillers provides extra protection for microorganisms against UVC radiation. Radiat. Res. 160, 198-204. doi: 10.1667/ $\operatorname{rr} 3027$

Conflict of Interest: The authors declare that the research was conducted in the absence of any commercial or financial relationships that could be construed as a potential conflict of interest.

Copyright (c) 2020 Vassilev, Vassileva, Martos, Garcia del Moral, Kowalska, Tylkowski and Malusá. This is an open-access article distributed under the terms of the Creative Commons Attribution License (CC BY). The use, distribution or reproduction in other forums is permitted, provided the original author(s) and the copyright owner(s) are credited and that the original publication in this journal is cited, in accordance with accepted academic practice. No use, distribution or reproduction is permitted which does not comply with these terms. 